\title{
Maj-Britt Mosegaard Hansen* \\ Cyclic changes to the negative coordinating conjunction from Latin to Modern French
}

https://doi.org/10.1515/flin-2021-2023

Received October 22, 2020; accepted March 4, 2021

Abstract: The evolution of the negative coordinating conjunction ('neither'/ 'nor') from Latin to Modern French instantiates a type of cyclic development that is previously undocumented as such at the level of morphosyntax, viz. a 'semasiological' cycle. In effect, the conjunction appears to have taken an almost perfectly circular path. Thus, in Classical Latin, as is consonant with the typological status of that language as a Double Negation language, neque/nec was exclusively used in negative contexts. Medieval French being a Negative Concord language, on the other hand, its negative coordinating conjunction, ne, a direct descendant of neque/nec, was able to develop a full range of weak negative polarity uses. In a range of contexts, ne was thus semantically equivalent to either the additive conjunction et ('and') or the disjunction ou ('or'). By the end of the Classical French period, however, the conjunction (which by then takes the form $n y / n i$ ) has lost all of its weak negative polarity uses again, and it is used only in strong negatively polar environments in Modern Standard French. Based on data from the electronic corpora Frantext and Base de Français Médiéval, I analyze the three stages of this evolution. I show that, together with other developments in the French negative system, it falsifies predictions made in the literature and has consequences for the reconstruction of negative systems in less well-documented languages.

Keywords: coordination; cyclicity; negation; polarity; reanalysis

\section{Introduction}

Semantically, the evolution of the negative coordinating conjunction ('neither'/ 'nor') from Latin to Modern French appears to have taken an almost perfectly circular path.

\footnotetext{
*Corresponding author: Maj-Britt Mosegaard Hansen, Department of Linguistics and English Language, School of Arts, Languages and Cultures, The University of Manchester, Manchester, UK, E-mail: Maj-Britt.MosegaardHansen@manchester.ac.uk
} 
Thus, in Classical Latin, as is consonant with the typological status of that language as a Double Negation language (cf. Section 2 below), neque/nec was exclusively used in negative contexts (Gianollo 2017; Orlandini and Poccetti 2007). Medieval French ${ }^{1}$ being a Negative Concord language (cf. Section 2), on the other hand, its negative coordinating conjunction, ne, a direct descendant of neque/nec, was able to develop a full range of so-called weak negative polarity uses (Antoine 1962; Buridant 2000; Foulet 1970; Martin and Wilmet 1980; for the notion of weak $v s$ strong negative polarity, cf. Section 2 below). In a range of contexts, ne was thus semantically equivalent to either the additive conjunction et ('and') or the disjunction ou ('or'). By the end of the Classical French period, however, the conjunction (which by then takes the form $n y / n i$ ) has lost all of its weak negative polarity uses again, and it is used only in strong negatively polar environments in Modern Standard French (Antoine 1962; Badiou-Monferran 2004, 2020a, 2020b).

Based on data from the electronic corpora Frantext and Base de Français Médiéval, I will analyze the three stages of this evolution. I will argue that the changes involved were a result, partly of the semantic-pragmatic characteristics of (a subset of) local contexts, and partly of broader morpho-syntactic changes that took place in the negative system at the relevant times, and I will explore the implications for historical linguistics of the evolution of the negative coordinating conjunction.

The paper is structured as follows: In Section 2, I outline the nature of Double Negation versus Negative Concord systems of negation, showing that Classical Latin and French represent different types. In Section 3, I outline the formal, syntactic, and semantic properties of the negative coordinating conjunction in Latin and Modern French, respectively, showing that although the range of syntactic contexts in which it can occur has been reduced in Modern French as compared to Latin, the conjunction has very similar semantic/pragmatic uses at these two stages of development. In Section 4, I show that the evolution from Latin to Modern French was, in fact, far from linear: on the contrary, in Medieval French a substantial extension took place with respect to the range of contexts in which the conjunction could be used, these extensions having, however, been gradually lost in the course of Renaissance and Classical French. Section 5

1 The following periodization will be used in this paper:

Old French: 843 to c. 1250 .

Middle French: c. 1250 to c. 1550 (Old and Middle French will together be referred to as 'Medieval French').

Renaissance French: c. 1550 to c. 1650.

Classical French: c. 1650 to c. 1800.

Modern French: c. 1800 to the present (this includes Contemporary French: c. 1950 to the present day). 
proposes explanations of the two successive sets of changes that the conjunction has undergone. Finally, in the concluding Section 6, I discuss implications for historical linguistics of the changes to the negative coordinating conjunction studied in this paper.

\section{The typology of negative systems}

Van der Auwera and van Alsenoy (2016), following Kahrel (1996), distinguish four types of negative systems in the world's languages, according to (a) the type of indefinites found in negative clauses, and (b) the interaction between verbal negators and indefinites occurring within one and the same clause. Two of these four patterns will be of interest here, namely on the one hand, the pattern known as Double Negation (henceforth DN), and on the other hand, the so-called Negative Concord (henceforth NC) pattern (e.g. de Swart 2010; Willis et al. 2013: 30). While both of these are in a typological minority according to van der Auwera and van Alsenoy's survey, NC in particular is frequent among Eurasian languages.

In DN languages such as Classical Latin (or Modern Standard English), negation functions mathematically, so to speak. In other words, each negative item occurring in a given clause will express one instance of negation, independently of whether it co-occurs with other negative items. Thus, two negative items within the same clause will cancel one another out and will yield an overall positive meaning. The precise type of negation expressed by the items in question, for instance the distinction between "standard" clause negation (Miestamo 2005: 1; Payne 1985: 198), expressed by the likes of Latin non, and quantifier negation (Payne 1985: 201), expressed by negative indefinites such as nemo ('no-one') or nihil ('nothing'), is immaterial. In DN languages, the latter type of expression can thus straightforwardly be classed as inherently negative indefinites.

The semantics of DN is illustrated in (1)-(5):

(1) Non videt.

not sees

'S/he/it does not see.'

(2) Nihil videt.

nothing s/he/it.sees

'S/he/it sees nothing.'

(3) Nemo videt.

nobody sees

'Nobody sees.' 
(4)

$\begin{array}{llll}\text { Adulantem nemo } & \text { non } & \text { videt. } \\ \text { flatterer } & \text { nobody } & \text { not } & \text { sees } \\ \text { 'Nobody does not spot a flatterer.' } \rightarrow \text { 'Everybody spots a flatterer.' (=DN) } \\ \text { (Cicero, De Amicitia 99) }\end{array}$

(5)

$\begin{array}{lll}\text { Nemo } & \text { nihil } & \text { videt. } \\ \text { nobody } & \text { nothing } & \text { sees } \\ \text { 'Nobody sees nothing.' } \rightarrow \text { 'Everybody sees something.' (=DN) }\end{array}$

In NC languages such as the Romance languages (including French), on the other hand, it is possible for at least a subset of negative expressions to be combined within a clause to express only a single negation. ${ }^{2,3}$ This subset normally includes

2 De Swart and Sag (2002) propose that NC is governed by a mechanism of resumptive quantification that results in the construction of polyadic quantifiers, whereas DN arises through iterative quantitification giving rise to scopal relations among the quantifiers. This account would need tweaking in order to accommodate the negative coordinating conjunction, which is not a quantifier. The precise nature of the compositional process responsible for $\mathrm{NC}$ is not central to the argument of the present paper, however.

3 It is worth pointing out that there may well be an 'undercurrent' of NC in languages that otherwise follow the DN pattern, such as Classical Latin or Modern Standard English, in both of which NC constructions may be used for emphatic purposes, cf. (i) and (ii):

$$
\begin{array}{lllll}
\text {... debebat } & \text { Epicrates } & \text { nummum } & \text { nullum } & \text { nemimi } \\
\text { owed } & \text { E. } & \text { money } & \text { no } & \text { to.nobody }
\end{array}
$$

'Epicrates owed no money to anybody.'

(Cicero, In Verrem 2.2.60, 1st c. BCE)

(ii) You ain't seen nothing yet!

Indeed, in the case of Latin, such an undercurrent appears to always have been present in the colloquial language, and we may assume that it contributed strongly to the emergence of NC in Romance. Specifically with respect to neque/nec, the pattern exemplified in (iii), brought to my attention by an anonymous reviewer and discussed by Murphy (1956), seems to provide further evidence of this NC undercurrent. Note, however, that analogous patterns are found in Modern Standard English (as Murphy 1956: 401 observes), as well as in Modern Standard Danish, both of which are DN languages, cf. (iv)-(v):

$\begin{array}{llllll}\text { nec } & \text { enim } & \text { cuiquam } & \text { bono } & \text { mali } & \text { quicquam } \\ \text { not } & \text { for } & \text { to.any } & \text { to.good(man) } & \text { of.evil } & \text { any(thing) } \\ \text { euenire } & \text { potest } & \text { nec } & \text { uiuo } & \text { nec } & \text { mortuo } \\ \text { come } & \text { can } & \text { neither } & \text { to.alive } & \text { nor } & \text { to.dead }\end{array}$

'For nothing bad can happen to a good man, whether he's alive or dead.' (Cicero, Tusculanae Disputationes I.99, cited in Murphy 1956: 400)

(iv) I won't do it, neither today nor tomorrow. 
indefinites, but may or may not include the standard clause negator, as well. The Modern Standard French equivalents of (1)-(5), given in (6)-(10) below, show that this language has so-called Negative Spread (de Swart 2010: 46), meaning that indefinites that are capable of expressing negation by themselves will normally express just one negation when combined with one another, but will express DN when combined with the standard clause negator. Note that, following Rowlett (1998: Ch. 1), I consider postverbal pas to be the standard clause negator in Modern French, the preverbal marker ne having the status of an optional agreement marker, whose presence or absence is largely determined by register (see further Section 5.2 below): ${ }^{4}$

(6)

Il ne voit pas.
he NEG.AGR sees not
'He does not see.'

(7)

$\begin{array}{llll}\text { Il } & \text { ne } & \text { voit } & \text { rien. } \\ \text { he } & \text { NEG.AGR } & \text { sees } & \text { nothing }\end{array}$

'He sees nothing./He does not see anything.'

(8)

$\begin{array}{lll}\text { Personne ne } & \text { voit. } \\ \text { nobody NEG.AGR } & \text { sees } \\ \text { 'Nobody sees.' } & \end{array}$

(9)

$\begin{array}{lllllll}\text { Personne } & n & a & \text { pas } & v u & \text { ce } & \text { panneau. } \\ \text { nobody } & \text { NEG.AGR } & \text { has } & \text { not } & \text { seen this sign }\end{array}$

'Nobody did not see that sign.' $\rightarrow$ 'Everybody saw that sign.' $(=\mathrm{DN})$

(10) Personne ne voit rien.

nobody NEG.AGR sees nothing

'Nobody sees anything.'(=NC)

(v) Jeg gør det ikke hverken idag eller imorgen.

I do it not neither today nor tomorrow.

'I'll do it neither today nor tomorrow.

4 As pointed out by a reviewer, preverbal ne may negate clauses on its own in certain contexts, even in Modern French. However, this is possible only in a handful of syntactic constructions of a vestigial nature, and apart from certain more or less frozen expressions such as n'importe quoi ('whatever'), the phenomenon is largely confined to formal registers (cf. Hansen 2016: 314-316). 
Furthermore, in NC languages, indefinites such as French personne ('no-one') and rien ('nothing') may often be used in a range of syntactic-semantic contexts that are not negative as such; for instance, comparatives like (11) below, or infinitival clauses governed by a lexically negative verb, as in (12). In such uses, the interpretation of the indefinite is therefore not negative, either, as the idiomatic translations show:

$$
\begin{aligned}
& \text { Tu le sais mieux que personne! } \\
& \text { you it know better than nobody } \\
& \text { 'You know that better than anybody!' }
\end{aligned}
$$

$$
\begin{aligned}
& \text { J' hésite à rien écrire sur Simone Weil ... } \\
& \text { I hesitate to nothing write about S.W. ... } \\
& \text { 'I hesitate to write anything about Simone Weil ...' } \\
& \text { (R. Aron, Mémoires, p. 78, cited in Muller 1991: 263) }
\end{aligned}
$$

Unlike the negative indefinites found in DN languages, indefinites used to express negation in NC languages thus have the following properties:

(i) They can express negation by themselves, including in elliptical contexts like (13):

$$
\begin{aligned}
& \text { Qui as -tu vu? - Personne. } \\
& \text { who have you seen nobody } \\
& \text { 'Who did you see? - Nobody.' }
\end{aligned}
$$

(ii) When co-occurring within one and the same clause, they typically express only a single negation, cf. (10) above, although DN readings can be forced (in the spoken language typically through suprasegmental means), as in (14):

$\begin{array}{llllc}\text { Personne } & n & a & \text { RIEN } & v u . \\ \text { nobody } & \text { NEG.AGR } & \text { has } & \text { NOTHING } & \text { seen } \\ \text { 'Nobody saw } & \text { NOTHING.' } & \rightarrow & \text { 'Everybody saw something.' }\end{array}$

(iii) They can occur in a specified range of non-negative contexts, cf. (11)-(12) above. The exact range of such contexts may differ synchronically from one item to the next (in the case of French, see Muller 1991: 265), and may expand and/or contract diachronically (e.g. Hansen 2012, 2014).

In contrast to inherently negative - or strongly negatively polar - contexts like (i) and (ii), the types of contexts included in (iii) are widely known as 'affective' or 'weakly negatively polar' contexts. Apart from syntactic contexts that are governed 
by (explicitly or implicitly) negative predicates such as (12), weak negative polarity contexts tend across languages to include interrogatives, conditionals, temporal 'before' comparatives (such as [11]), privative 'without' clauses, and various others. Arguably, what such contexts have in common is that they implicitly evoke at least the possibility of negation; e.g. if X knows something better than Y (as in [11] above), then Y does not know it as well as X; or if one hesitates to do something (as in [12]), one is inclined not to do it (cf. Linebarger 1987). ${ }^{5}$

Indefinites and other types of expressions that are capable of occurring in both strong and weak negative polarity contexts in NC languages are commonly known as 'n-words' (following Laka Muzarga 1990: 108), or more recently, 'negative concord items', or NCIs (Breitbarth et al. 2020: 14). Since the negative indefinites of DN languages are incompatible with weak negative polarity contexts, such languages often make use of a separate set of expressions, known as 'negative polarity items', or NPIs, in those contexts, as well as in strong negative polarity contexts governed by the standard clause negator. In English, for instance, the negative indefinite noseries (no-one, nothing etc.) contrasts with the any- series (anyone, anything, etc.), whose members are NPIs. ${ }^{6}$

5 Ladusaw (1980) famously argues that weak negative polarity contexts have the logical property of being downward entailing. While downward entailment does, indeed, characterize several of the major types of weak negative polarity contexts, it is considerably more problematic to describe other contexts that prominently accept NPIs across languages, such as interrogatives, in this manner (cf. Linebarger 1987). Subsequently, Giannakidou (2002) has proposed replacing downward entailment with the broader notion of non-veridicality. The types of contexts defined as nonveridical, however, include several which do not accommodate NCIs with non-negative meaning, such as habituals and modal verb constructions. Conversely, they appear to exclude some contexts that do admit NCIs, such as relative clauses with a superlative antecedent. For these reasons, the concepts of downward entailment and non-veridicality will not be appealed to in the present study.

6 This is not meant to suggest that the existence of NPIs is confined to DN languages. Despite being an NC language, French, too, possesses various forms that are used as NPIs (e.g. qui/quoi que ce soit 'anybody/-thing (at all)', lit. 'who-/whatever it may be'), as in (i) below. Unlike the corresponding NCIs, French NPIs combine freely with the standard clause negator, as the example demonstrates. They are, however, considerably less frequent than NCIs, particularly in strong negative polarity contexts:

(i) Il n' a pas vu quoi que ce soit.

he NEG.AGR has not seen whatever.it.may.be

'He didn't see anything (at all).' 
Armed with the concepts and distinctions set out in this section, we are now in a position to take a closer look at the negative coordinating conjunction and its properties in Latin and French, both Medieval and Modern.

\section{Properties of the negative coordinating conjunction in Classical Latin versus Modern French}

\subsection{Etymology and formal properties}

The Modern French negative coordinating conjunction ni originates in Latin neque (a univerbation of the archaic negative marker ne and the enclitic coordinating particle -que, 'and'; cf. Gianollo 2017: 62; Orlandini and Poccetti 2007: 31) and its phonologically shortened form nec. In the transition from Latin to Medieval French, neque/nec becomes ne through phonological erosion. At that stage of the French language, the negative coordinating conjunction was thus formally identical to what at the time was the standard clause negator, viz. the preverbal ne (cf. [15] below), the latter representing a phonologically reduced form of the Latin standard negator non.

$\begin{array}{llll}\text { Se cest acorde } & \text { ne volez } & \text { otrier, } \\ \text { if this agreement not you.will consent.to } & \text { con } \\ \text { En Sarraguce vus } & \text { vendrat } & \text { aseger ;... } \\ \text { in S. } & \text { you } & \text { will.come besiege }\end{array}$

'If you will not consent to this agreement, He will come and besiege you in Saragoza; ...'

(Roland, vv. 475-476, c. 1100)

Starting in the 15th c., the coordinating conjunction ne gradually begins to be replaced by the Modern form ni (which is not infrequently written ny until the Classical French period). In the literature, it is sometimes assumed that ni results from univerbation of ne with the demonstrative pronoun iceluy or the masculine singular subject pronoun il (cf. Badiou-Monferrand 2020a: 948; Pope 1934: §598). I find that etymology implausible, partly because neither of the suggested combinations is particularly frequent in my Medieval French corpus data, ${ }^{7}$ and partly because the form $n i$ is attested in Northern and North-Eastern dialects from around

7 See Section 4.1 below for an overview of the diachronic data and sampling methods used in this paper. 
1200 (cf. [16] below), and sporadically elsewhere from the 14th c. This suggests that the evolution from ne > ni may be a simple case of raising and fronting of the vowel in certain phonological contexts. Be that as it may, by the end of the 16th c., the form $n y / n i$ has become fully generalized, and ne is no longer attested as a conjunction in my corpus data.

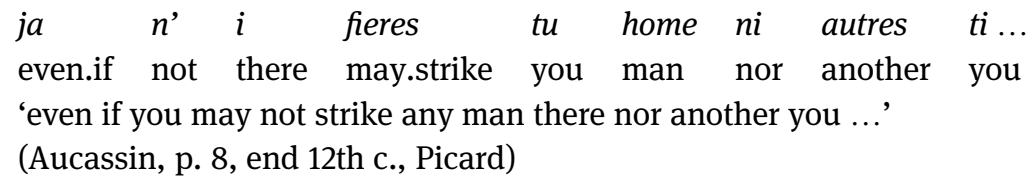

\subsection{The syntax and semantics of Classical Latin neque/nec}

As described by Orlandini and Poccetti (2007) and Gianollo (2017), the Classical Latin negative coordinating conjunction inherently expresses negation, and thus only occurs in strong negative polarity context (cf. Section 2 above). Although it always expresses clause negation as defined by Klima (1964), the conjunction may connect either constituents or clauses, as seen in (17)-(20) below. At both levels, neque/nec may be used bisyndetically (Haspelmath 2007: 6), as in (17)-(18) or monosyndetically (Haspelmath 2007: 6), as in (19)-(20). In both cases, the conjunction is prepositive, i.e. it precedes the clause or constituent in its scope. Haspelmath (2007: 11) notes that, across languages, prepositive bisyndesis invariably constitutes an emphatic variant of prepositive monosyndesis.

\begin{tabular}{cccc}
...nec & \multicolumn{1}{c}{$\begin{array}{c}\text { meliores } \\
\text { neither }\end{array}$} & $\begin{array}{c}\text { better } \\
\text { because.of this }\end{array}$ & $\begin{array}{l}\text { scientiam } \\
\text { knowledge }\end{array}$ \\
nec & beatiores & esse possumus & \\
nor & happier & be & we.can
\end{tabular}

'...we can be neither better nor happier because of this knowledge.' (Cicero, De Republica 1.32, 1st c. BCE)

(18) Caput dolet neque audio nec oculis prospicio satis head hurts neither I.hear nor with.eyes I.see enough 'My head hurts, and I can't hear nor can I see very well with my eyes.' (Plautus, Amphytrion 1059, 3rd-2nd c. BCE) 


...quam me quacumque ratione posset non iudicio neque
than me whichever manner he.could not by.trial nor
disceptatione sed vi atque impressione evertere
by.dispute but by.violence and by.attack bring.down
'...than to bring me down, in whichever way he could, not by trial nor
dispute, but by violence and attack.'
(Cicero, Ad familiares 5.2.8., 1st c. BCE, cited in Gianollo 2017: 64)

(20)

$\begin{aligned} & \text {...quae mei testes non dicunt } \\ & \text { which my }\end{aligned}$ witnesses not say
quia
because non not therunt sciunt
'... (those things) that my witnesses don't say, because they haven't seen
them nor do they know them.'
(Cicero, Pro Tullio 10.24, 1st c. BCE)

When used monosyndetically, the conjunction may connect two negatives as in (19)-(20), but it also frequently connects a negative clause or constituent to a preceding positive one, as in (21)-(22):

(21) ...patebat via et certa neque longa lay.open road both safe and.not long 'A road, both safe and not long, lay open.'

(Cicero, Phillipicae 11.2.4, 1st c. BCE)

\begin{tabular}{|c|c|c|c|c|c|}
\hline $\begin{array}{l}\text { Ex his } \\
\text { of these } \\
q u i \\
\text { those.who }\end{array}$ & $\begin{array}{l}\text { omnibus } \\
\text { all } \\
\text { Cantium } \\
\text { Kent }\end{array}$ & $\begin{array}{l}\text { longe } \\
\text { by.far } \\
\text { incolunt } \\
\text { inhabit }\end{array}$ & $\begin{array}{l}\text { sunt } \\
\text { are }\end{array}$ & $\begin{array}{l}\text { nanissimi } \\
\text { t.civilized }\end{array}$ & \\
\hline $\begin{array}{ll}\text { quae } & \text { re } \\
\text { which } & \text { re }\end{array}$ & $\begin{array}{ll}\text { regio } & \text { est } \\
\text { region } & \text { is }\end{array}$ & $\begin{array}{l}\text { maritima } \\
\text { maritime }\end{array}$ & $\begin{array}{l}\text { omnis, } \\
\text { all }\end{array}$ & & \\
\hline $\begin{array}{l}\text { neque } \\
\text { and.not }\end{array}$ & $\begin{array}{l}\text { multum } \\
\text { much }\end{array}$ & $\begin{array}{l}a \\
\text { from }\end{array}$ & $\begin{array}{l}\text { Gallica } \\
\text { Gallic }\end{array}$ & $\begin{array}{l}\text { differunt } \\
\text { differ }\end{array}$ & $\begin{array}{l}\text { consuetudine } \\
\text { way.of.life }\end{array}$ \\
\hline
\end{tabular}

'Of all these, the inhabitants of Kent, an entirely maritime district, are by far the most civilized and do not differ much from the Gallic way of life.' (Caesar, De bello gallico 5.14, 1st c. BCE)

As discussed by Orlandini and Poccetti (2007: §3) and Gianollo (2017: §4.2), Latin neque/nec could also be used adverbially as a scalar focus particle. This use of the negative coordinating conjunction - which according to Haspelmath (2007: 17) is not uncommon across languages - is a relatively late development in Latin. First 
attested as an invited inference in Early Imperial Latin (Lewis and Short 1879) in examples such as (23), it becomes more common in Late Latin:

$\begin{array}{llllll}\text { Ita } & \text { primis } & \text { repulsis } & \text { Maharbal } & \text { cum maiore robore } \\ \text { thus } & \text { first } & \text { repulsed } & \text { M. } & \text { with greater power } \\ \text { virorum missus } & \text { nec } & \text { ipse } & \text { eruptionem } & \\ \text { of.men sent } & \text { and.not } & \text { himself } & \text { sally } & \\ \text { cohortium } & \text { sustinuit } & & & \\ \text { of.cohorts sustained } & & & \end{array}$

'Thus, after the first (forces) had been repulsed, Maharbal himself (despite) having been sent with greater manpower - did also not sustain the cohorts' sally/even Maharbal himself - (despite) having been sent with greater manpower - did not sustain the cohorts' sally.' (Livy, $A b$ urbe condita 23.18.4, 27-9 BCE, cited in Gianollo 2017: 68)

As indicated by the two alternative translations of (23), I find it plausible to assume that this scalar use grows fairly directly out of the basic 'and not' meaning of neque/ nec, when used in contexts of counterexpectation, such as this one.

\subsection{The syntax and semantics of Modern French ni}

Semantically, Modern French ni is like Latin neque/nec in being confined to strong negative polarity contexts. $N i$ further resembles its Latin forebear syntactically in as much as it is prepositive and may be used bisyndetically or monosyndetically. A key difference is that, French being an NC language from its inception, ni does not normally negate a clause on its own, but must be accompanied by the preverbal clause negator ne. In contemporary informal registers where preverbal ne tends to be dropped (cf. Hansen 2013: 64), ni is seldom used: thus, in the 63-hour spoken CLAPI corpus, ni is attested a mere 97 times. By comparison, the basic additive conjunction et ('and') is attested 21,515 times. A further difference between the Latin and the Modern French conjunction is that Modern French ni cannot connect a negative clause or clause-like element with a preceding positive one:

$$
\begin{aligned}
& \text { *Je l' aime ni ne le déteste. } \\
& \text { I him love and.not NEG.AGR him hate } \\
& \text { 'I love him and don't hate him.' }
\end{aligned}
$$


When used bisyndetically, ni normally connects two negative constituents at the sub-clausal level, as in (25):

$$
\begin{aligned}
& \text { Je n' aime ni le vin blanc ni le vin rouge. } \\
& \text { I NEG.AGR like neither the wine white nor the wine red } \\
& \text { 'I like neither white wine nor red wine.' }
\end{aligned}
$$

It is possible for ni to (monosyndetically) conjoin two finite verbs, provided they have the same subject, as in (26). ${ }^{8}$ In such cases, the verbs will normally be in the same tense and will have similar complements, if any. Arguably, thus, such examples can be considered to be cases of constituent conjunction, rather than clause conjunction, cf. Togeby (1984: §1505):

$$
\begin{aligned}
& \text { Je ne l' aime ni ne le déteste. } \\
& \text { I NEG.AGR him love nor NEG.AGR him hate } \\
& \text { 'I neither love him nor hate him.' }
\end{aligned}
$$

$\mathrm{Ni}$ behaves like an NCI in being able to combine with other NCIs within the same clause, to yield a single-negation interpretation, as in (27):

$$
\begin{aligned}
& \text { Rien ni personne ne } m \text { ' empêchera de faire ceci! } \\
& \text { nothing nor nobody NEG.AGR me will.prevent from do this } \\
& \text { 'Nothing and nobody will prevent me from doing this!' }
\end{aligned}
$$

On the other hand, as an NCI, ni cannot normally be used in combination with the standard clause negator ne-pas within the same clause. Thus (28) below can only be interpreted as expressing double negation, in which case it carries strong metalinguistic overtones:

$$
\begin{aligned}
& \text { ?Pierre n' } \quad \text { a pas ni } \quad b u \quad \text { ni mangé. } \\
& \text { P. NEG.AGR has not neither drunk nor eaten } \\
& \text { 'Pierre hasn't had neither food nor drink.' }
\end{aligned}
$$

When connecting subordinate clauses, as in (29), ni is typically used monosyndetically, following ne-pas in the main clause, although bisyndesis is also a possibility (Mouret 2005: 82). Unambiguous cases of ni conjoining two main clauses, such as that in (30), are rare (if not non-existent) in contemporary French. Examples like that in (31) are, however, more typical of the use of monosyndetic ni. While ni appears to be conjoining two direct objects, i.e. two sub-clausal constituents, in this case, the fact that the second conjunct is normally preceded by a comma (or, if spoken, by an intonation break) suggests that it rather has the status of an ellipted clause. That analysis receives additional support from the fact that,

8 Some, but not all, speakers also accept bisyndesis, cf. Mouret (2005: 72). 
as the examples show, this use of ni does not trigger a DN interpretation, despite being preceded by the standard clause negator ne-pas. This is expected if the ne-pas token in fact occurs in a different clause:

$\begin{array}{llllllll}\text { Je ne } & \text { pense } & \text { pas que Marie } & \text { soit venue, } \\ \mathrm{I} & \text { NEG.AGR } & \text { think } & \text { not that } & \text { M. } & \text { is come } \\ \text { ni } & \text { ' } & \text { elle } & \text { ait } l & \text { intention de venir. } \\ \text { nor that } & \text { she } & \text { has the intention to come }\end{array}$

'I don't think Marie has come, nor that she's planning to.'

(30)

$\begin{array}{llllll}\text { Mais } & \text { nous } & \text { ne } & \text { devons } & \text { pas } & \text { oublier, } \\ \text { but } & \text { we } & \text { NEG.AGR } & \text { must } & \text { not } & \text { forget } \\ \text { ni } & \text { personne } & \text { ne } & \text { doit } & \text { oublier } & \text { que... } \\ \text { nor } & \text { nobody } & \text { NEG.AGR } & \text { must } & \text { forget } & \text { that }\end{array}$

'But we mustn't forget, nor must anyone forget that ...'

(Josset, cited in Sten 1938: 187)

(31) Je n' aime pas le vin blanc, ni le vin rouge.

I NEG.AGR like not the wine white nor the wine red 'I don't like white wine, nor red wine.'

As observed by Antoine (1962: 1060-1063) and Roig (2016: 59), Modern French ni can (albeit only very sporadically) give rise to a scalar interpretation, as in (32) below. In this use, which is similar to the scalar focus-particle use of Latin neque/ nec exemplified in (23) above, ni always co-occurs with the additive coordinating conjunction et in my data. As coordinating conjunctions cannot normally be combined, this suggests that $n i$ has been reanalyzed as a focus particle and is no longer perceived as a coordinating conjunction itself. This sense is not infrequently reinforced by the presence of other scalar expressions, such as surtout ('particularly'/'above all') and même ('even'/'-self'):

$\mathrm{Ni}$ le corbeau, depuis longtemps, ni la pie,
neither the crow since long.time nor the magpie
et ni le merle, ne m' ont parlé de Zeus.
and nor the blackbird NEG.AGR to.me have spoken of Z.
'Neither the crow, for a long time, nor the magpie, and not even the
blackbird, have talked to me about Zeus.'
(Giono, L'eau vive, 128, 1943)

The following section looks more closely at the evolution of the negative coordinating conjunction between Late Latin and the Modern French period, showing that - despite what one might spontaneously tend to infer from the data adduced 
in the present section, its syntactic and semantic evolution has been far from linear.

\section{The evolution of the negative coordinating conjunction in Medieval French}

\subsection{Data used}

The data is taken from two diachronic corpora. For the 9th-15th centuries, I have made use of the Base de Français Médiéval (henceforth, BFM), and for the 16th-21st c., of Frantext. Both were sampled throughout the period surveyed, concentrating in the Medieval period on texts originating from the langue d'oil region, albeit excluding more peripheral dialects such as Anglo-Norman.

From 1150 onwards, text sampling took place at regular intervals in each century. The BFM contains very few texts composed prior to 1150, several of which are very short. Moreover, because some of the changes that are of interest in this section began during this Very Early Old French period and continued to develop particularly quickly until the end of the 12th c., it was deemed important to include as much relevant data as possible. Similarly, I included more texts in the 17th-20th c. sample: not only do uses of the negative coordinating conjunction that were relatively common in the Medieval and Renaissance period gradually disappear after the 16th c., but in addition, use of the conjunction as such declines. As I wanted to be able to track the disappearance of the older uses more closely, while nevertheless keeping the total number of tokens manageable in terms of the qualitative analysis required, it seemed sensible to include more texts sampled at shorter intervals. The breakdown of texts in my database is shown in Table 1.

Table 1: Texts sampled by period.

\begin{tabular}{ll}
\hline Period & Number of texts \\
\hline $842-1099$ & 4 texts \\
$1100-1149$ & 8 texts \\
$1150-1199$ & 5 texts \\
$1200-1599$ & 5 texts/century \\
$1600-1799$ & 6 texts/century \\
$1800-1899$ & 7 texts \\
$1900-1999$ & 6 texts \\
\hline
\end{tabular}


Automatic searches were carried out for the forms ne, ni, and ny in the BFM and for the forms ni and ny in Frantext. Subsequently, due to the formal identity in Medieval French between the conjunction ne and the preverbal standard negator ne, some degree of manual sorting had to be carried out on the BFM data, given that the automatic syntactic categorization of tokens in that database is not always fully reliable. Table 2 provides a breakdown of the number of relevant tokens identified.

Table 2: Tokens of the negative coordinating conjunction by period.

\begin{tabular}{lrr}
\hline Period & Total number of tokens & Normalized frequency/10,000 words \\
\hline Pre-11th c. & 5 & 165.01 \\
11th c. & 30 & 39.72 \\
1st half 12th c. & 386 & 42.5 \\
2nd half 12th c. & 842 & 58.12 \\
13th c. & 1,286 & 37.2 \\
14th c. & 1,155 & 29.2 \\
15th c. & 365 & 18.25 \\
16th c. & 1,115 & 19.81 \\
17th c. & 269 & 15.61 \\
18th c. & 193 & 11.2 \\
19th c. & 267 & 8.75 \\
20th c. & 107 & 4.38 \\
\hline
\end{tabular}

\subsection{Syntactic and semantic changes to the negative coordinating conjunction between Latin and Modern French}

As noted above, French is an NC language from its inception, the evolution from a DN to an NC system of negation having been well under way already in Late Latin (cf. Hansen and Molinelli forthcoming). The conjunction ne is attested in the earliest extant text, Les Serments de Strasbourg (842), in the passage reproduced in (33). This is a strong negative polarity context, as indicated by the presence of the clause negator non in the governing clause:

\begin{tabular}{llll} 
Si Lodhuvigs & \multicolumn{2}{l}{ sagrament, que son fradre Karlo jurat, conservat } \\
if L. & oath & that his brother $\mathrm{K}$. & swore keeps \\
et Karlus, & meos sendra, de suo part non l=ostanit \\
and K. & my lord & of his part not it=observes
\end{tabular}




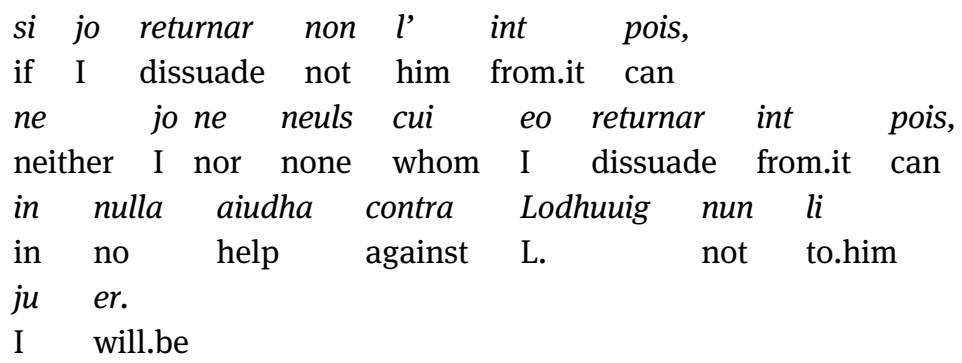

'If Louis keeps the oath that he has sworn to his brother Charles, and Charles, my lord, on the other hand breaks it, and if I cannot dissuade him from it neither I nor anyone that I can dissuade from it - then I shall not help him in any way against Louis.'

Throughout the Medieval period, the majority of instances of the conjunction ne are used in this type of context, and like Latin neque/nec, ne can be used to connect both constituents and clauses, cf. (34)-(35). As these examples show, ne also has both bisyndetic and monosyndetic uses, similarly to neque/nec. What is not attested anywhere in my Medieval and Renaissance data, on the other hand, is an adverbial, scalar focus particle use of ne corresponding to the use of neque/nec seen in (23), Section 3.2 above. This latter function of the marker appears to have been lost in the transition from Latin to French.

(34) Ne eschipre ne esturman de son droit

$\begin{array}{llll}\text { neither captain nor pilot of its right } \\ \text { cors nen ert certan; } & & & \\ \text { course } & \text { not was certain } & & \end{array}$

'Neither the captain nor the pilot was certain of the right direction.'

(Enéas, 205, 1155)

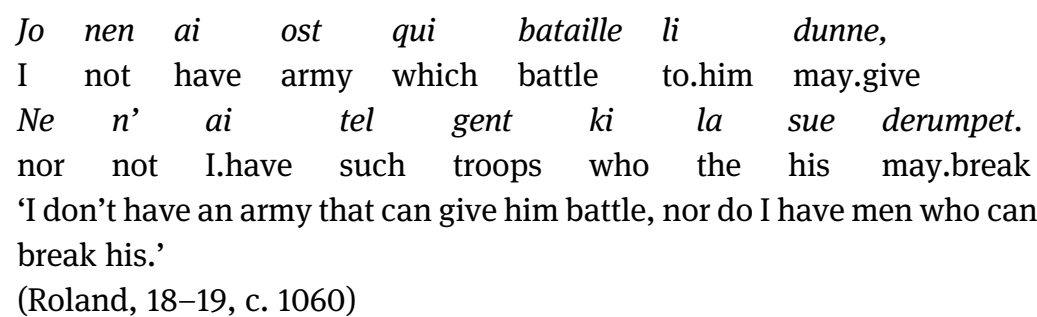


From the mid-11th c. onwards, however, a change seems to occur, ${ }^{9}$ and ne starts to appear in a range of weak negative polarity contexts where neque/nec are not found in Classical Latin, nor ni in Modern French (Antoine 1962: Ch. 5; BadiouMonferran 2004, 2020b; Buridant 2000: 556-557; Foulet 1970: 288; Martin and Wilmet 1980: 274). Table 3 provides a breakdown of the absolute numbers of such uses per period in my data, along with the percentage of the total number of uses of the negative coordinating conjunction that they represent.

Table 3: Weak negative polarity uses of $n e / n y / n i$ by period.

\begin{tabular}{lr}
\hline Period & Weak negative polarity uses of $\boldsymbol{n e} / \boldsymbol{n} \boldsymbol{y} / \mathbf{n i}$ \\
\hline Pre-11th c. & $0(0 \%)$ \\
11th c. & $1(3.7 \%)$ \\
1st half 12th c. & $29(7.5 \%)$ \\
2nd half 12th c. & $110(13 \%)$ \\
13th c. & $141(11 \%)$ \\
14th c. & $162(14 \%)$ \\
15th c. & $55(15 \%)$ \\
16th c. & $75(6.7 \%)$ \\
17th c. & $15(5.6 \%)$ \\
18th c. & $3(1.6 \%)$ \\
19th c. & $0(0 \%)$ \\
20th c. & $0(0 \%)$ \\
\hline
\end{tabular}

According to Badiou-Monferran (2020b: 1664), the form ny/ni occurs "almost exclusively" in strong negative environments. While the decline of weak negative polarity uses of the negative coordinating conjunction very clearly does coincide with the gradual switch from ne to $n y / n i$, this claim is not borne out as such in my data. Up until the end of the 16th c., in texts where the two forms are in competition, they occur in weak negative polarity environments with proportionately similar frequencies, and from the 17th c. onwards, where the percentage of weak negatively polar uses of the conjunction does not differ markedly from that of the previous century, only the newer form $n y / n i$ is found.

9 This statement is deliberately hedged, as the small number of texts composed prior to 1100 makes it impossible to exclude that the change had already happened in proto-Romance, and is simply not represented in the French textual record until La vie de Saint Alexis in 1050. The gradual rise in the frequency of occurrence of $n e$ in weak negative polarity contexts over the following one hundred years does, however, suggest that the change took place in Old French. 
The main types of weak negative polarity contexts in which the conjunction is found are the following:

(i) Subordinate clauses governed by a negative main clause:

$\begin{array}{llll}\text { Unches } & \text { ne } & \text { fud } & \text { ami } \\ \text { never } & \text { not } & \text { was } & \text { friend } \\ \text { Qui } & a=l & \text { busuign } & \text { failli } \\ \text { who } & \text { at=the } & \text { need } & \text { failed } \\ \text { Dum } & \text { il } & \text { poüst } & \text { aider } \\ \text { when } & \text { he } & \text { could } & \text { help } \\ \text { Ne } & \text { de } & \text { ren } & \text { conseiller } \\ \text { nor } & \text { of } & \text { nothing } & \text { advise }\end{array}$

'There never was a friend who failed when there was a need to help or advise on anything.'

(Comput, 170, 1113-1119)

(ii) Clauses containing a negatively oriented expression (such as mar in [37]), or subordinate clauses governed by a negatively oriented main clause (38):

$\begin{array}{lllllcr}A & \text { lui } & \text { trenchier } & \text { mar } & & \text { querras } & \text { fer } \\ \text { to } & \text { it } & \text { cut } & \text { to.your.disadvantage } & \text { will.seek } & \text { iron } \\ \text { ne } & \text { nul } & \text { trenchant } & \text { qui } & \text { soit } & d & \text { acier } ; . . . \\ \text { nor } & \text { no } & \text { blade } & \text { which } & \text { is } & \text { of } & \text { steel }\end{array}$

'Seeking to cut it with iron, or any blade made of steel, will do you no good; ...'

(Enéas, 2317, 1155)

(38)

... car male chose seroit qu' il peust contremander for bad thing would.be that he could cancel Ne essoinier pour l' autre...

nor excuse.from.appearing for the other

'... for it would be a bad thing if he could cancel or excuse himself from appearing in the other ...'

(Beauma1, 66, c. 1283)

(iii) Comparatives of inequality:

(39) ...car plus blanche ert que nois ne glace;... for more white she.was than snow nor ice

'...for she was whiter than snow or ice; ...'

(Enéas, 3994, 1155)

(iv) Conditionals:

(40) $\mathrm{Se}=\mathrm{l}$ pois trover a port ne a passage if =him find in pass nor in gorge 
Liverrai lui une mortel bataille.

I.will.wage to.him a deadly battle

'If I can find him in a pass or in a gorge, I'll wage a deadly battle against him.' (Roland, 657, c. 1100)

(v) Direct and indirect interrogatives, mainly (but not exclusively) of the yes/no variety:

Quidez vus dunc $k$ ' il surrexist, ne qu' il
think you then that he rose nor that he
vus puisse guarantir?
you can protect

'So do you think that he was resurrected and that he can protect you?'

(Gormont, 192, c. 1130)

\begin{tabular}{llllll}
...si & \multicolumn{1}{l}{ se } & \multicolumn{2}{l}{ merveillerent } & dont & il pot \\
and.so & REFL & they.wondered & from.where & he could \\
avoir si & bele gent & ne si bele chevalerie. \\
have so fine troops & nor so fine knighthood
\end{tabular}

'... and they wondered where he could have got such fine troops and such fine knights.'

(Morée, 257, 1320-1324)

(vi) Concessive constructions, frequently (but not exclusively) taking the form of expressions involving a more or less fixed pair of antonyms:

\begin{tabular}{|c|c|c|c|c|}
\hline $\begin{array}{l}\text { Ambure } \\
\text { both } \\
\text { qui=l } \\
\text { that=him }\end{array}$ & $\begin{array}{l}\text { ocit } \\
\text { he.kills } \\
\text { lot. } \\
\text { praises }\end{array}$ & $\begin{array}{l}k i \\
\text { who }\end{array}$ & $\begin{array}{l}q u e=l \\
\text { that }=\text { him }\end{array}$ & $\begin{array}{l}\text { blasme } \\
\text { blames }\end{array}$ \\
\hline
\end{tabular}

'He kills them both, whoever blames or praises him.'

(Roland, 1589, c. 1100)

(vii) Temporal clauses, mainly anteriors:

(44) ...j' en puis porter tout ce que j' $i$ ai,

I of.it can take all that which I there have

ainçois qu' il en porte riens

before he of.it takes nothing

ne qu' il $i$ mete le pié.

nor that he there sets the foot

'...I can take all I've got of it there, before he takes any of it or sets foot there.'

(Beaumanoir, 167, c. 1300) 
(viii) Relative clauses following a non-negative antecedent, which is frequently indefinite, virtual, or - as in (45) - superlative in meaning:

.. mais vos di je qu' il m' avint
but to.you say I that it to.me happened
une des plus merveilleuses aventures dou monde,
one of.the more marvellous adventures of.the world
ni qui onques au mien escient
nor which never to.the my knowledge
avenist a home.
happened to man

'... but I tell you that one of the world's most marvellous adventures befell me, and which to my knowledge never happened to anyone before.'

(Qgraal, 209b, c. 1225-1230)

Not infrequently, a given example may involve more than one of the context types listed above, as in (46), where we have an antonymical concessive structure inside an interrogative:

...cum fus unkes si os
how you.were never so daring
Que me saisis ne $\quad$ a dreit ne a tort?
that me you.seized neither by right nor by wrong
'...how did you ever dare to seize me, whether rightly or
wrongly?'

(Roland, 2293, c. 1100)

All the context types listed above are attested at least once in my data by the first half of the 12th c. A few additional context types are very sporadically found from the late 13th c. onwards. Each of the latter is confined to a single text in the data base. Although interrogatives are the first context type to be attested in the data (already in the 11th c.), subordinate clauses governed by a negative main clause constitute the dominant environment across the centuries from the 12th to the 16th c. The frequency with which the remaining contexts are attested varies across the centuries, with no obvious pattern.

By the time we reach the 17th c., only two context types are attested in my data, in roughly equal proportions. On the one hand, subordinate clauses governed by a negative main clause (cf. [36] above) are attested, and on the other hand, the broadly similar context type constituted by clauses containing a negatively oriented expression, or subordinate clauses governed by a negatively oriented main clause (cf. [37]-[38]). Finally, in the 18th c., only these context types and interrogatives remain, confined to two texts, and each represented by only a single 
attestation. The one interrogative found expresses a rhetorical question oriented towards a negative answer.

Weak negative polarity uses of $n i$ are evidently already disappearing in the second half of the 17th c., being represented in only the earliest of the three texts from this period. It is thus hardly surprising that the three 18th-c. examples are all found in those context types that are intuitively closest to being strongly negatively polar in nature. This is in line with the observations made by Badiou-Monferran (2004: 75).

As for the scalar focus particle use observed in both Latin and Modern French, it is not attested in my data base prior to the 20th c. Possibly, this may be explained by the fact that the scale expressed by focus particles of this type in strong negative environments will in most cases be reversed in weak negatively polar ones, as shown in (47)-(49) below. Thus, if a marker is specified for the former, as Latin neque/nec and Modern French et ni both are, then extension to the latter kind of environment will entail a semantic/pragmatic shift which may be too radical to be accomplished easily.

Not even Paul came./Even Paul didn't come. >> Paul was the most likely person to come.

If even Paul came, then ... >> Paul was the least likely person to come.

(49) Did even Paul come? >> Paul was the least likely person to come.

\section{Explaining the changes to the negative coordinating conjunction}

Based on the above, we now have two changes in need of explanation. The first one is the change that appears to occur in Early Old French, from ne being compatible only with strong negative contexts to its becoming regularly used in weak negative polarity environments. The second change is the disappearance in the Classical French period of weak negative polarity uses of $n i$.

\subsection{From strong to weak negative polarity}

Starting with the former, recall that Classical Latin was a DN language, whereas Old French had already transitioned to NC status. Thus, as we saw in Section 3.2, 
Latin neque/nec would negate clauses in the absence of any other marker of negation. Old French ne, in contrast, was normally accompanied by the formally identical preverbal standard negative marker ne. In and of itself, this change in the negative system could have predisposed the conjunction ne to undergo semantic change by 'dissimilation', as it were. ${ }^{10}$ In other words, an Old French language user hearing a sentence like (50), in which there are three occurrences of the form ne, in the first and third case in a syntactic position where it evidently serves to negate its host clause, viz. immediately preceding the finite verbs, may easily have inferred that the second ne, which occurs between the two negated clauses, was not meant to express negation as such, but that it functioned rather as a marker that it was appropriate to use in negative polarity environments more broadly.

Tu n' ies mes hom ne jo ne sui tis sire.
you not are my man nor I not am your lord
'You're not my subject, and I'm not your lord.'
(Roland, 297, c. 1100)

In addition to this in-built systemic rationale for reanalyzing ne, a more specific type of facilitating context can be identified. We saw in Section 3.2 that Latin neque/nec could connect a negative clause to a preceding positive one, as in example (22). While the Modern French conjunction ni does not offer this possibility (cf. example [24] in Section 3.3), its Old French forebear ne did, as shown in (51):

\begin{tabular}{llccccc} 
En & Rencesval & irai & Rollant & \multicolumn{2}{l}{ ocire, } & \\
in & R. & & I.will.go & R. & kill & \\
Ne & Oliver & $n$, & en & porterat & la & vie. \\
nor & O. & not & of.him & will.save & the & life
\end{tabular}

'To Roncevaux will I go to kill Roland, and Olivier will not save his life.' (Roland, 964, c. 1100)

Importantly, both Latin and Old French could also construct sentences of this type using the conjunction et ('and') followed by the standard clause negator instead of neque/nec or ne:

$\begin{array}{llll}\text { satis } & \text { scire origini Romanae et deos adfuisse } \\ \text { enough } & \text { know } & \text { origins Roman both gods have.been.present } \\ \text { et } & \text { non defuturam virtutem; ... } \\ \text { and } & \text { not } & \text { will.be.absent worth }\end{array}$

10 I owe the suggestion of this term, which I am using loosely to describe a meaning-driven, rather than a phonology-driven, process, to Eitan Grossman. 
'They knew well both that the gods had been present at Rome's origins, and that valor would not be lacking; ...'

(Livy, Ab urbe condita 1.9.4, 1st c. BCE-1st c. CE)

Anaz en es et non es ci.
gone from.there is and not is here
'He has gone and is not here.'
(Passion, 102, c. 1000)

Because Classical Latin was a DN language, however, negation is only expressed once in this type of sentence, independently of whether the speaker/writer chooses the neque/nec construction or the et+standard clause negation construction. As an NC language, Old French, on the other hand, presents its users with a choice of two constructions conveying the same meaning, one of which involves a single formally negative element, while the other involves two such elements. This choice may plausibly be assumed to have further favored the reanalysis of the conjunction ne in contexts like (51) above.

Finally, it is worth pointing out that the acquisition of weak negative polarity uses by the negative coordinating conjunction is not an isolated development in Medieval French, where a number of other etymologically and morphologically negative expressions have been shown to have evolved in a similar way (cf. Hansen and Molinelli forthcoming; Ingham 2011; Labelle and Espinal 2014).

This is true, saliently, of a variety of NCIs formed by univerbation of Latin collocations with ne (c), such as nesun (< Lat. ne + ipse 'self' + unum 'one'), negun (< Lat. nec + unus) (both of which translate as 'no[ne]' or 'nobody'), or nient ('nothing' < Lat. ne gente [m] 'people'), but also of nul ('no[ne]'), which is a direct descendant of the Latin negative indefinite nullus:

\begin{tabular}{lllllll} 
Virun & \multicolumn{2}{l}{ en } & vunt & .xl. & dis & \\
approximately & from.there & they.go & 40 & days & \\
Ainzque en & nul & port & se & seient & mis, ... \\
before in & no & port & REF & they.are & put
\end{tabular}

'They sail around for approximately 40 days before finding their way into any port, ...'

(StBrend, 632, early 12th c.)

$$
\begin{aligned}
& \text { Se il voz weult de noient encuser, ... } \\
& \text { if he you wants.to of nothing } \\
& \text { 'If he wants to accuse you of anything, ... } \\
& \text { (Amiamil, 720, c. 1200) }
\end{aligned}
$$


One item, the focus particle neïs ('[not] even' < Lat. ne ipse), could even be used in straightforward positive polarity contexts, as shown in (57):

\begin{tabular}{lcccccc} 
Ne & portez & rien & \multicolumn{2}{c}{ od } & vus & $d$ ici, \\
not & take & nothing & \multicolumn{2}{c}{ with } & you & from here \\
Neïs & un & punt & de & cest & cunrei,... & \\
not.even & a & point & of & this & supply
\end{tabular}

'Don't take anything with you from here, not even any of these provisions, ...'

(StBrend, 331, early 12th c.)

(57)

Femmes fist $\quad$ ocire e enfanz
women he.made kill and children
Neïs les petiz alaitanz;
even the little breast-feeding
'He had women and children killed, even babes at the breast;'
(Brut2, 14422, c. 1155)

Of these, only nul has survived into Modern French, where it is nowadays largely confined to formal registers. However, Hansen (2012, 2014) has shown that some of the present-day French NCIs, prominently the temporal adverbs jamais ('never') and plus ('anymore') - despite being etymologically positive - similarly appear to have acquired uses in strong negative polarity contexts first, before becoming licensed in weak negative polarity contexts.

\subsection{From weak back to strong negative polarity}

As can be seen in Table 3, Section 4.2 above, the change going in the opposite direction commences in the 16th c. and is essentially complete by the 19th c., where no more weak negative polarity uses of ni are found in my data. A combination of factors seems likely to have motivated the loss of these uses. On the one hand, the so-called Jespersen Cycle (Jespersen 1917) which affects the expression of standard clause negation in French by gradually effecting a shift from preverbal to postverbal negation, may be assumed to have played a central role. The form taken by this cycle from Latin to French is outlined in Table 4.

By the 16th c., Jespersen's Cycle had reached Stage 3 in French, resulting in a general weakening of the preverbal clitic clause negator ne. A new phonetically and morphosyntactically stronger postverbal negative marker pas, originally optional and confined to marked discourse-pragmatic contexts (Hansen 2013: §2.2.1), had become fully generalized, and there is textual evidence that no later 
Table 4: Jespersen's Cycle in French.

\begin{tabular}{|c|c|c|}
\hline Stage 0. (Latin) & $\begin{array}{l}\text { non dico 'I do } \\
\text { not say' }\end{array}$ & Simple preverbal negation \\
\hline Stage 1. & je ne dis & $\begin{array}{l}\text { Phonetically reduced simple preverbal } \\
\text { negation }\end{array}$ \\
\hline Stage 2. & je ne dis (pas) & $\begin{array}{l}\text { Preverbal negation optionally reinforced by } \\
\text { postverbal marker }\end{array}$ \\
\hline Stage 3. & je ne dis pas & Bipartite negation embracing the verb \\
\hline Stage 4. & je (ne) dis pas & $\begin{array}{l}\text { Postverbal negation with optional prever- } \\
\text { bal negative agreement marker }\end{array}$ \\
\hline $\begin{array}{l}\text { Stage 5. (Informal contemporary } \\
\text { spoken Canadian French) }\end{array}$ & je dis pas & Simple postverbal negation \\
\hline
\end{tabular}

than the early 17th c., preverbal ne was already sporadically deleted in the spontaneous speech of children and lower class speakers, at least, meaning that the language was slowly entering Stage 4 of the Cycle. In the course of Modern French, (non-)use ne has become principally linked to register, and deletion is now so common in informal registers that the syntactically and semantically redundant preverbal marker has been cogently argued to fulfil a mere negative agreement function, while postverbal pas is the true standard clause negator (Rowlett 1998). It seems plausible that this weakening of preverbal ne may have predisposed language users to attribute an increasingly stronger negative force to the conjunction ni in bisyndetic contexts (such as [25] in Section 3.3 above), where ni, rather than pas, accompanied ne. This may have been further reinforced by the formal change in the conjunction from ne to $n i$, whose more phonetically salient vowel stands in contrast to the weaker schwa of the preverbal negator.

Another reinforcing aspect is the fact that, even at their 15th-c. peak, weak negative polarity uses of the conjunction never constitute more than $15 \%$ of its total number of uses (cf. Table 3, Section 4.2). Although the former uses are salient enough not to escape the notice of anyone who is conversant with Medieval French, contexts of strong negative polarity are nevertheless overwhelmingly more frequent throughout the centuries, and it will thus have been comparatively easy for the conjunction to gradually become reassociated exclusively with such contexts.

Thirdly, although as shown in Sections 3.3 and 4.2, it is at any stage of the French language the norm for $n e / n y / n i$ to co-occur with preverbal $n e$, the conjunction can in fact very occasionally be found in contexts where it negates a clause on its own, e.g. (58). This, too, may - albeit to a modest degree - have 
contributed to making the attribution of a strong negative semantics to the marker a fairly straightforward step:

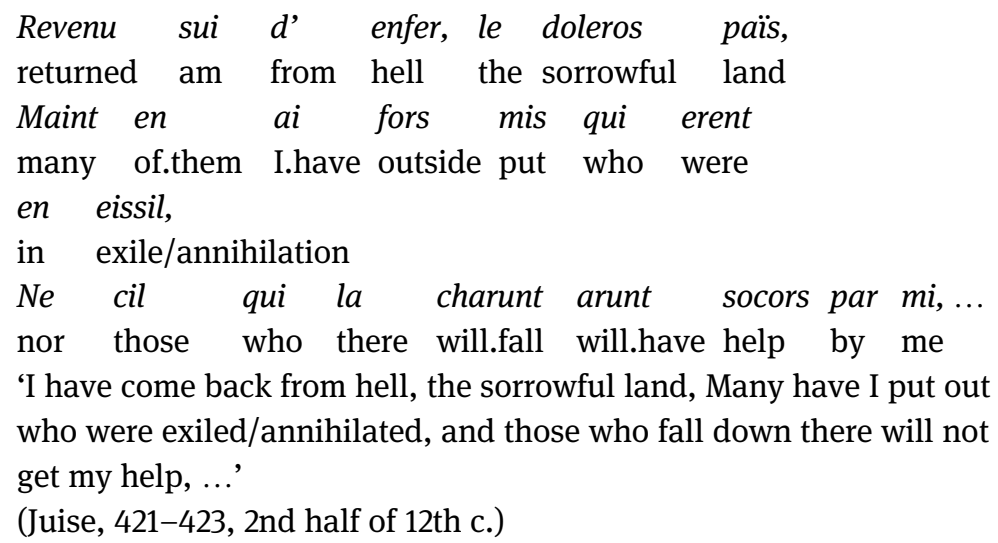

Finally, there is an intriguing analogy between the respective evolution of $n i$ and the indefinite nul ('no[ne]'): apart from preverbal ne and the particle non (used variably as a response particle, as an adverb and as a negative prefix), these are the only two morphologically negative markers inherited from Latin that have survived the Medieval period in French. All other negative expressions in the Modern French language (incl. the Modern standard clause negator pas and indefinites such as rien 'nothing', personne 'nobody', jamais 'never', etc.) are French innovations with non-negative etymologies. As shown in Section 5.1, nul, too, acquires weak negative polarity uses in Medieval French, but subsequently sheds these uses in the transition to Modern French, where - unlike the 'native' indefinites - it is (with sporadic exceptions) compatible more or less exclusively with strong negative polarity context, and where, like ni, it is largely confined to formal contexts in which systematic retention of preverbal ne is still the norm. An explanation of this analogy awaits further study, but its existence suggests that the two etymologically negative markers may have mutually influenced one another's diachronic trajectory.

\section{Conclusions}

In this section, I look more closely at the nature of the changes undergone by the negative coordinating conjunction, and their consequences for historical linguistics. 
In the first instance, the present study raises questions pertaining to the grammaticalization of polarity indefinites. Haspelmath (1997: 230) makes the strong claim that indefinites grammaticalize unidirectionally along a cline that includes the types of uses in (59):

$$
\text { Polarity neutral }>\text { weak negative polarity }>\text { strong negative polarity }
$$

While the negative coordinating conjunction is not an indefinite, its evolution nevertheless adds to a growing body of evidence that Haspelmath's proposed cline cannot be assumed to hold in all languages. The relevant body of counterevidence of course includes the additional Medieval French items discussed in Section 5.1, some of which are indefinites, as well as examples from German adduced by Jäger (2010). Prominently, this has consequences for the reconstruction of languages whose histories are less well attested than those of French or German, in as much as it cannot be assumed without further evidence that, if a language has a marker that synchronically has two or more of the adjacent uses in (59), then the uses on the lefthand side of that cline must be diachronically older than those that are further to the right. Not only can polarity expressions develop in either direction, but - as the present study has shown - one and the same item may successively move in opposite directions, and it may do so independently of the direction taken by other polarity expressions within the same language.

Secondly, we have seen that at the level of its semantics, the evolution of the negative coordinating conjunction from Latin to Modern French has indeed been bi-directional, from being confined to strong negative polarity contexts in Latin to having weak negative polarity uses in Medieval and Renaissance French, and then back to strong negative polarity contexts only in Modern French. Interestingly, in both stages where the conjunction is confined to strong negative environments, but not in the middle stage where it is regularly found also in weak negative polarity contexts, it has an additional use as a scalar focus particle. In French, this use appears to be quite a late development, found only in the 20th c., where $n i$ is otherwise in overall decline.

At this level of description, the path taken may thus be described as almost perfectly circular, as illustrated in Figure 1.

Syntactically, on the other hand, the changes that have taken place are rather more complex in nature. Not only is the syntax of the negative coordinating conjunction affected by a fundamental shift in the negative system, from DN to NC, in the transition from Latin to French, but it has also arguably been affected by the well-known Jespersen-Cycle changes to the expression of standard clause 


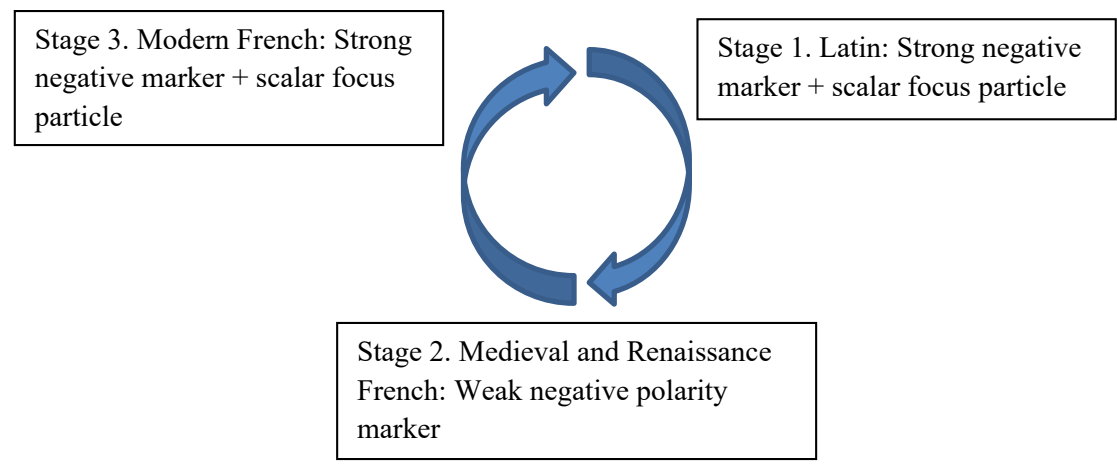

Figure 1: Semantic changes to the negative coordinating conjunction: a circular evolution.

negation in French, which appear to have contributed to the loss of its uses in syntactic contexts with weakly negatively polar semantics. Finally, for reasons that are not clear, the Modern French conjunction has also lost a subset of its earlier uses in interclausal contexts with strongly negatively polar semantics (cf. Section 3.3 above).

When the semantic and syntactic levels are considered together, what appeared above as a circular path therefore looks rather more spiral-like: syntactically, the Medieval French conjunction retains all of the range of both subclausal and interclausal uses of its Latin forebear, with the exception of the scalar focus-particle use, but also extends that range into the territory of weak negative polarity, with attendant semantic changes. In the transition to Modern French, the conjunction essentially restricts its range, both semantically and syntactically (apart from the marginal development of a scalar focus-particle use), but whereas in the former respect it essentially rejoins Latin, it goes well beyond that language in terms of syntactic restrictions on its use. This is (imperfectly) illustrated in Figure 2.

This more spiral-like than strictly circular form is, in fact, characteristic of so-called (morpho-)syntactic cycles, a phenomenon that includes, but is not limited to, the Jespersen Cycle mentioned above (cf. Meillet 1921 [1912]: 140). Thus, van Gelderen (2011) identifies seven such cycles that are attested crosslinguistically, and additional ones have been posited for individual languages, for instance the interrogative cycle proposed by Waltereit (2020).

What makes the negative coordinating conjunction particularly interesting in this connection is that, unlike Jespersen's Cycle, its evolution does not involve the replacement of an older marker (e.g. the French preverbal negator ne) by a newer one (e.g. French postverbal pas), which originally has a different (if overlapping) function, but which gradually takes on the functional profile of the older marker, 


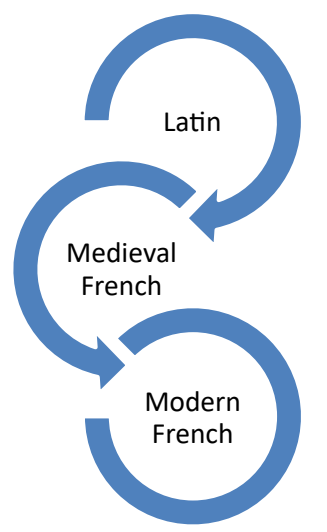

Figure 2: Semantic changes to the negative coordinating conjunction revised: a spiral-like evolution.

with the result that the older marker increasingly falls out of use (cf. Section 5.2 above). Instead, in the present case, what is etymologically one and the same linguistic item extends its functional profile, only to subsequently retract to something that in many ways resembles its starting point.

Discussing the diachronic rise of pragmatic markers, Hansen (2018) observes that this type of evolution may similarly take place in a cyclic manner, and makes a distinction between two subtypes of semantic-pragmatic cycles (or cycles of pragmaticalization), viz. semasiological and onomasiological cycles. The latter involve renewal of an older item by a newer, etymologically unrelated, one. Extending Hansen's (2018) model to (morpho-)syntactic cycles, the classic Jespersen Cycle would thus be of this onomasiological type. The former, semasiological, type of semantic-pragmatic cycle involves one and the same - originally truth-conditional item developing one or more new uses as a non-truth-conditional pragmatic marker, then at a later stage restricting its functional profile back to its historical starting point, only to once more develop pragmatic-marker uses of a similar (but not quite identical) nature to the ones it had previously lost.

The evolution of the negative coordinating conjunction would seem to instantiate just such a semasiological cycle, but at the (morpho-)syntactic level, where - to my knowledge - this type of cycle has not previously been attested. The fact that both of the above types of cycle can be found across the (morpho-) syntactic level and the semantic-pragmatic level suggests a parallelism, hence the existence of possible connections, between cyclic changes at both levels that are deserving of further exploration. 
Acknowledgments: I would like to thank the handling editors of Folia Linguistica Historica, the two anonymous reviewers, and Johan van der Auwera, for helpful comments on previous versions of this paper. It goes without saying that I take full responsibility for any remaining errors.

\section{References}

Antoine, Gérald. 1962. La coordination en français, vol. 2. Paris: D’Artrey.

Badiou-Monferran, Claire. 2004. Négation et coordination en français classique : le morphème ni dans tous ses états. Langue Française 143. 69-92.

Badiou-Monferran, Claire. 2020a. Les coordonnants et, ou, ni et les locutions coordonnantes. In Christiane Marchello-Nizia, Bernard Combettes, Tobias Scheer \& Sophie Prévost (eds.), Grande grammaire historique du français, 944-961. Berlin \& Boston: Mouton de Gruyter.

Badiou-Monferran, Claire. 2020b. Sémantique des coordonnants et, ou, ni. In Christiane Marchello-Nizia, Bernard Combettes, Tobias Scheer \& Sophie Prévost (eds.), Grande grammaire historique du français, 1654-1678. Berlin \& Boston: Mouton de Gruyter. Base de Français Médiéval. Electronic database of Medieval and Early Renaissance French. http:// txm.bfm-corpus.org/ (accessed February 2020).

Breitbarth, Anne, Christopher Lucas \& David Willis. 2020. The history of negation in the languages of Europe and the Mediterranean, vol. 2: Patterns and processes. Oxford: Oxford University Press.

Buridant, Claude. 2000. Grammaire nouvelle de l'ancien français. Paris: SEDES.

Corpus CLAPI. Electronic database of spoken French. http://clapi.ish-lyon.cnrs.fr/V3_Accueil. php?interface_langue $=F R$ (accessed February 2021).

Foulet, Lucien. 1970. Petite syntaxe de l'ancien français, 3rd edn. Paris: Honoré Champion.

Frantext. Electronic database of historical and contemporary written French. https://www. frantext.fr/ (accessed May 2020).

Gelderen, Elly van. 2011. The linguistic cycle. Oxford: Oxford University Press.

Giannakidou, Anastasia. 2002. Licensing and sensitivity in polarity items: From downward entailment to (non)veridicality. Chicago Linguistic Society 38. 29-53.

Gianollo, Chiara. 2017. Focus-sensitive negation in Latin. Catalan Journal of Linguistics 16. 51-77. Hansen, Maj-Britt Mosegaard. 2012. On the evolution of temporal n-words in Medieval French. Language Sciences 34(1). 76-91.

Hansen, Maj-Britt Mosegaard. 2013. Negation in the history of French. In David Willis, Christopher Lucas \& Anne Breitbarth (eds.), The history of negation in the languages of Europe and the Mediterranean, vol. 1: Case studies, 51-76. Oxford: Oxford University Press.

Hansen, Maj-Britt Mosegaard. 2014. The grammaticalization of negative indefinites: The case of the temporal/aspectual $\mathrm{n}$-words plus and mais in Medieval French. In

Maj-Britt Mosegaard Hansen \& Jacqueline Visconti (eds.), The diachrony of negation, 185-212. Amsterdam \& Philadelphia: John Benjamins.

Hansen, Maj-Britt Mosegaard. 2016. The structure of Modern Standard French. A student grammar. Oxford: Oxford University Press.

Hansen, Maj-Britt Mosegaard. 2018. Cyclic phenomena in the evolution of pragmatic markers. Examples from Romance. In Salvador Pons Bordería \& Oscar Loureda Lamas (eds.), Beyond 
grammaticalization and discourse markers. New issues in the study of language change, 51-77. Leiden: Brill.

Hansen, Maj-Britt Mosegaard \& Piera Molinelli. Forthcoming. Negation from Late Latin to Early French: Pragmatics, discourse traditions, and directionalities. In Anne Carlier, Rembert Eufe, Céline Guillot-Barbance \& Maria Selig (eds.), Bridging the gap between Late Latin and Early French: Empirical investigations of (morpho)syntactic changes. Berlin \& Boston: Mouton de Gruyter.

Haspelmath, Martin. 1997. Indefinite pronouns. Oxford: Oxford University Press.

Haspelmath, Martin. 2007. Coordination. In Timothy Shopen (ed.), Language typology and syntactic description, vol. 2: Complex constructions, 2nd edn., 1-51. Cambridge: Cambridge University Press.

Ingham, Richard. 2011. Grammar change in Anglo-Norman and Continental French. The replacement of non-affirmative indefinite nul by aucun. Diachronica 28(4). 441-467.

Jespersen, Otto. 1917. Negation in English and other languages. Copenhagen: Høst \& Søn. Jäger, Agnes. 2010. Anything is nothing is something. On the diachrony of polarity types of indefinites. Natural Language \& Linguistic Theory 28. 787-822.

Kahrel, Peter. 1996. Aspects of negation. Amsterdam: University of Amsterdam dissertation.

Klima, Edward S. 1964. Negation in English. In Jerry A. Fodor \& Jerrold J. Katz (eds.), The structure of language: Readings in the philosophy of language, 246-323. Englewood Cliffs, NJ: PrenticeHall.

Labelle, Marie \& Maria Teresa Espinal. 2014. Diachronic changes in negative expressions: The case of French. Lingua 145. 194-225.

Ladusaw, William. 1980. Polarity sensitivity as inherent scope relations. New York: Garland.

Laka Muzarga, Miren Itziar. 1990. Negation in syntax: On the nature of functional categories and projections. Harvard, MA: Massachusetts Institute of Technology dissertation.

Lewis, Charlton T. \& Charles Short. 1879. A Latin dictionary. New York: Harper \& Sons. http://www. perseus.tufts.edu/hopper/text?doc=Perseus:text:1999.04.0059:entry=neque (accessed February 2020).

Linebarger, Marcia. 1987. Negative polarity and grammatical representation. Linguistics and Philosophy 10. 325-387.

Martin, Robert \& Marc Wilmet. 1980. Syntaxe du moyen français. Bordeaux: Bière.

Meillet, Antoine. 1921 [1912]. L'évolution des formes grammaticales. In Antoine Meillet (ed.), Linguistique historique et linguistique générale, 130-148. Paris: Honoré Champion.

Miestamo, Matti. 2005. Standard negation. The negation of declarative verbal main clauses in a typological perspective. Berlin \& New York: Mouton de Gruyter.

Mouret, François. 2005. La syntaxe des coordinations corrélatives du français. Langages 160. 67-92.

Muller, Claude. 1991. La négation en français. Syntaxe, sémantique et éléments de comparaison avec les autres langues romanes. Geneva: Droz.

Murphy, Paul R. 1956. The origins and survival of a Latin negative pattern. American Journal of Philology 77(4). 396-407.

Orlandini, Anna \& Paolo Poccetti. 2007. Il y a nec et nec. Trois valeurs de la négation en latin et dans les langues de l'Italie ancienne. In Franck Floricic (ed.), La négation dans les langues romanes, 29-47. Amsterdam \& Philadelphia: John Benjamins.

Payne, John R. 1985. Negation. In Timothy Shopen (ed.), Language typology and syntactic description, vol. 1: Clause structure, 1st edn., 197-242. Cambridge: Cambridge University Press. 
Pope, Mildred Katharine. 1934. From Latin to modern French with especial consideration of AngloNorman: Phonology and morphology. Manchester: Manchester University Press.

Roig, Audrey. 2016. Ni ... ni : des corrélatifs déterminants? In Antoine Gautier, Eva Havu \& Dan van Raemdonck (eds.), Déterminations, 47-68. Bern: Peter Lang.

Rowlett, Paul. 1998. Sentential negation in French. Oxford: Oxford University Press.

Sten, Holger. 1938. Nægtelserne i fransk [Negative markers in French]. Copenhagen: Nyt Nordisk Forlag/Arnold Busck.

Swart, Henriëtte de. 2010. Expression and interpretation of negation. An OT typology. Dordrecht: Springer.

Swart, Henriëtte de \& Ivan A. Sag. 2002. Negation and negative concord in Romance. Linguistics and Philosophy 25. 373-417.

Togeby, Knud. 1984. Grammaire française, vol. 4: Les mots invariables. Magnus Berg, Ghani Merad \& Ebbe Spang-Hanssen (eds.). Copenhagen: Akademisk Forlag.

Van der Auwera, Johan \& Lauren Van Alsenoy. 2016. On the typology of negative concord. Studies in Language 40(3). 473-512.

Waltereit, Richard. 2020. Parallels between the negative cycle and the rise of interrogative marking in French. In Maj-Britt Mosegaard Hansen (ed.), The role of pragmatics in cyclic language change. [Special issue]. Journal of Historical Pragmatics 21 (2). 264-289.

Willis, David, Christopher Lucas \& Anne Breitbarth. 2013. Comparing diachronies of negation. In David Willis, Christopher Lucas \& Anne Breitbarth (eds.), The history of negation in the languages of Europe and the Mediterranean, vol. 1: Case studies, 1-50. Oxford: Oxford University Press. 